\title{
Pembelajaran Matematika dengan Penerapan Model Kooperatif Tipe Talking Stick Terhadap Siswa Kelas VII SMP
}

\author{
Ma'rup, Andi Mulawakkan Firdaus
}

(C) 2020 JEMS (Jurnal Edukasi Matematika dan Sains)

This is an open access article under the CC-BY-SA license (https://creativecommons.org/licenses/bysa/4.0/) ISSN 2337-9049 (print), ISSN 2502-4671 (online)

\begin{abstract}
Abstrak:
Penelitian ini bertujuan untuk mengetahui keefektifan penerapan model pembelajaran Talking Stick pada siswa kelas VII SMP tahun ajaran 2019/2020. Jenis penelitian ini adalah penelitian pra-eksperimen dengan melibatkan satu kelas/kelompok sebagai kelas eksperimen, dengan desain penelitian yaitu One Group Pre-test and Post-test Design. Sampel dalam penelitian ini yaitu siswa kelas VII yang terdiri dari 26 orang siswa. Penelitian ini dilakukan selama 4 kali pertemuan. Instrumen yang digunakan dalam penelitian ini adalah lembar tes hasil belajar, lembar observasi, lembar aktivitas siswa, dan lembar angket respon siswa. Hasil penelitian menunjukkan bahwa: (1) Skor rata-rata hasil belajar matematika siswa sebelum diterapkan model Kooperatif Tipe Talking Stick adalah 33.13, dimana 26 siswa kelas VII memperoleh skor sangat rendah. Sedangkan skor hasil belajar siswa setelah diterapkan model Kooperatif Tipe Talking Stick meningkat menjadi 82.72, dan diperoleh 22 siswa atau $84.7 \%$ tuntas secara individu, (2) Aktivitas siswa berada dalam kategori baik, (3) Respons siswa terhadap proses pembelajaran matematika dikelas melalui model Kooperatif Tipe Talking Stick memberikan respon positif. Berdasarkan hasil penelitian tersebut disimpulkan bahwa penerapan model Kooperatif Tipe Talking Stick sangat efektif diterapkan dalam pembelajaran matematika siswa kelas VII SMP Saribuana Makassar pada materi bilangan bulat.
\end{abstract}

Kata Kunci: Model Kooperatif Tipe Talking Stick, Hasil belajar, Aktivitas Siswa, Respon Siswa.

\begin{abstract}
:
This study aims to determine the effectiveness of the application of the Talking Stick learning model in seventh grade students of the 2019/2020 school year. This type of research is a preexperimental research involving one class / group as an experimental class, with research designs namely One Group Pretest and Post-test Design. The sample in this study was VII grade students consisting of 26 students. This research was conducted during 4 meetings. The instruments used in this study were learning achievement test sheets, observation sheets, student activity sheets, and student questionnaire responses sheets. The results showed that: (1) The average score of students' mathematics learning outcomes before applying the Cooperative Type Talking Stick model was 33.13, where 26 grade VII students scored very low. While the score of student learning outcomes after applying the Cooperative Type Talking Stick model increased to 82.72 , and obtained 22 students or $84.7 \%$ completed individually, (2) Student activities are in good categories, (3) Student responses to the mathematics learning process through the Cooperative model The Talking Stick type provides a positive response. Based on the results of the study it was concluded that the application of the Talking Stick Cooperative Type model was very effectively applied in mathematics learning for Grade VII students of Saribuana Makassar Middle School on integer material.
\end{abstract}

Keyword: The Talking Stick Type Cooperative Model, Learning Outcomes, Student Activities, Student Responses.

\section{Pendahuluan}

Pendidikan memiliki peranan yang sangat penting dalam pembangunan SDM di Indonesia. Oleh karena itu, pendidikan sangat perlu untuk dikembangkan dari berbagai ilmu pengetahuan,

Ma’rup, Pendidikan Matematika Universitas Muhamadiyah Makasar

Ma'rup@unismuh.ac.id

Andi Mulawakkan Firdaus, Pendidikan Matematika Universitas Muhamadiyah Makasar

Andi.mulawakkan@unismuh.ac.id 
sebab pendidikan yang berkualitas dapat meningkatkan kualitas suatu bangsa. Dimana mutu pendidikan sangat perlu diperhatikan dalam mencapai sebuah tujuan pendidikan, untuk mutu pendidikan sendiri dilihat dari sebuah keberhasilan yang dicapai oleh seorang siswa dalam mengikuti proses pembelajaran. Hal yang sanagt penting dari proses pembelajaran tersebut yaitu kegiatan menekankan arti dari belajar bagi seorang siswa agar hasil belajar yang diraih dapat bermanfaat bagi kehidupan dimasa mendatang.

Berdasarkan hasil observasi pada bulan Oktober 2019 diketahui bahwa hasil belajar matematika siswa kelas VII SMP Saribuana Makassar masih dalam kategori rendah. Hal ini dapat dilihat dari hasil ulangan MID yang menunjukkan nilai rata-rata siswa adalah 65,4 dengan nilai maksimal 100. Adapun dari 20 siswa yang mengikuti ulangan, hanya 9 orang yang mencapai Kriteria Ketuntasan Minimal (KKM) yang ditetapkan oleh sekolah adalah 75.

Hal yang sama dikemukakan guru bidang Studi Matematika SMP Saribuana Makassar pada saat penulis mewawancarai pada bulan Oktober 2019. “Tingkat penguasaan/pencapaian seorang siswa pada mata pelajaran matematika sangat rendah jika dibandingkan dengan mata pelajaran lain. Rendahnya hasil belajar matematika siswa sebagaimana diuraikan pada hasil observasi di atas menunjukkan ketidakmampuan siswa dalam menyelesaikan permasalahan (soal) yang dihadapi, karena siswa merasa tidak termotivasi dalam belajar dan pembelajaran yang cenderung membosankan dalam kelas.

Guru harus menciptakan suasana yang menyenangkan pada proses pembelajaran mata pelajaran matematika. Banyak cara yang bisa dilakukan seorang guru sehingga siswa memiliki perasaan bahagia/gembira. Guru berperan sebagai pelaksana proses pembelajaran dalam meningkatkan kualitas cara mengajarnya, sehingga siswa lebih mudah memahami materi pelajaran. Adapun metode yang dilakukan yaitu dengan menggunakan metode pembelajaran yang bervariasi dan tidak membosankan kepada siswa yang tentunya disesuaikan dengan materi pembelajaran.

Berdasarkan uraian diatas perlu diterapkan suatu metode pembelajaran yang mampu membuat siswa termotivasi/tertantang dalam meningkatkan hasil belajarnya. Maka peneliti melakukan tindakan alternatife dalam mangatasi masalah yaitu dengan menerapkan model pembelajaran yang membuat siswa aktif dan memberi siswa kesempatan berbicara didepan kelas untuk meningkatkan potensi secara maksimal. Model pembelajaran yang di maksud adalah model pembelajaran kooperatif.

Model kooperatif tipe talking stick merupakan salah satu model yang dapat meningkatkan keaktifan dan kerjasama siswa. Talking stick dapat merangsang pikiran siswa dalam pembelajaran, memfasilitasi siswa dengan berbagai pengalaman belajar siswa sehingga siswa dapat memiliki sikap kepemimpinan. Selain untuk meningkatkan keaktifan berbicara pada siswa, metode pembelajaran ini juga mampu membuat siswa termotivasi dan lebih aktif dalam peroses pembelajaran.

Metode pembelajaran yang diterapkan dalam penelitian ini adalah metode talking stick. Dimana metode tersebut yang menggunakan tongkat sebagai media dalam proses pembelajaran. Tongkat diberikan kepada salah satu siswa dan siswa tersebut yang pegang tongkat wajib/harus menjawab pertanyaan yang diutarakan oleh seorang guru. Dengan metode seperti ini dapat membuat siswa termotivasi dan meningkatkan mental siswa untuk siap menghadapai masalah pada kondisi apapun.

Adapun penelitian terdahulu yang dilakukan oleh Ramayanti dkk, (2011) hasil analisis data yang diperoleh yaitu kelas eksperimen adalah 9,12 dengan standar deviasi yaitu 2,58 sedangkan untuk kelas kontrol adalah 5,67 dengan standar deviasi yaitu 2,33. Adapun hasil pengujian 
hipotesis yaitu -3,88 dan 1,96 pada skor 0,05, sehingga $\mathrm{H} 0$ ditolak dan $\mathrm{H} 1$ diterima. Hasil ini menunjukkan terdapat perbedaan yang signifikan pada hasil belajar matematika siswa yang diajar melalui model Pembelajaran Kooperatif Tipe Talking Stick dengan siswa yang diajar dengan pembelajaran konvensional. Adapun Penelitian Belina, dkk (2015) dimana hasil belajar dikelas VII SMP Negeri Air Satan setelah diterapkan model kooperatif tipe Talking Stick sudah berhasil/tuntas. Siswa kelas VII SMP Negeri Air Satan memperoleh nilai rata-rata sebesar 81,81 dengan persentase jumlah siswa yang berhasil mencapai KKM sebesar 76\%.

Selain penelitian tersebut Penelitian Hidayati, dkk (2017) menunjukkan adanya perbedaan hasil belajar siswa yang diajar dengan penerapan model kooperatif tipe talking stick dengan pembelajaran konvensional. Sehingga dapat disimpulkan bahwa model pembelajaran kooperatif tipe talking stick dapat digunakan dalam proses pembelajaran. Selain itu Penelitian yang dilakukan oleh Mallisa (2014) bahwa Model Pembelajaran Kooperatif Tipe Talking Stick efektif diterapkan pada siswa kelas VII SMPN Sangalla' pada materi operasi hitung bilangan bulat berdasarkan 4 (empat) kriteria yang dikemukakan peneliti yaitu kemampuan guru menerapkan model Talking Stick, aktivitas siswa, hasil belajar, dan respon siswa. Penelitian ini didukung oleh Amir (2016) yang mengatakan bahwa model kooperatif tipe talking stick membuat pembelajaran menjadi menarik dan menyenangkan, dan siswa bersemangat dan lebih giat belajar matematika sehingga hasil belajar matematika lebih baik.

Selanjutnya Penelitian yang dilakukan oleh Diah Laila Khasanah, dkk (2013) menunjukkan bahwa model pembelajaran kooperatif tipe talking stick lebih efektif diterapkan pada materi aljabar di kelas VIII di SMP Negeri 1 Kranggan, dibandingkan model pembelajaran konvensional. Fakta di lapangan dapat memberikan gambaran sekaligus motivasi bagi peneliti untuk melakukan penelitian dengan tujuan untuk mengetahui kefektifan pembelajaran melalui Penerapan Model Kooperatif Tipe talking Stick Pada Siswa Kelas VII SMP Saribuana Makassar. Dengan metode ini siswa diharapkan dapat mengikuti pembelajaran dengan aktif, dan dapat melatih siswa untuk lebih semangat/termotivasi untuk belajar sendiri dirumah.

\section{Metode}

Jenis Penelitian ini yaitu penelitian eksperimen dengan melibatkan satu kelas/ kelompok, dengan desain pra eksperimen, penelitian ini bertujuan untuk mengetahui gambaran efektivitas pembelajaran matematika melalui model kooperatif tipe talking stick pada siswa kelas VII SMP Saribuana Makassar.

Desain penelitian ini yaitu "One Group Pretest-Posttest Design", dimana satu kelompok eksperimen yang diberikan preetest sebelum perlakuan dengan penerapan model talking stick dan posttest setelah perlakuan dengan penerapan model talking stick. Dengan demikian dari hasil perlakuan dapat ditemukan hasil yang akurat kerena dapat dibandingkan terhadap situasi/kondisi sebelum diberikan perlakuan.

Populasi dalam penelitian ini yaitu seluruh siswa kelas VII SMP Saribuana Makassar tahun pelajaran 2019/2020 dengan jumlah kelas yaitu 3 rombel. Teknik pengambilan sampel dalam penelitian ini menggunakan Cluster Random Sampling yaitu dengan menentukan satu kelas secara acak dari 3 kelas dengan pertimbangan karakteristik setiap kelas adalah homogen dalam hal kemampuan matematika maupun kurikulum.

Instrumen penelitian yang akan digunakan yaitu tes hasil belajar, lembar aktivitas siswa, lembar observasi, dan angket respons siswa. Pengumpulan data hasil belajar dikumpulkan dengan menggunakan metode tes. Preetest adalah tes awal yang dilaksanakan sebelum adanya 
perlakuan. Posttest adalah tes akhir yang dilaksanakan setelah memberikan perlakuan. Untuk mengetahui perbedaan kemampuan siswa dalam pelajaran matematika setelah mendapat perlakuan.

Data tentang aktivitas siswa dalam proses pembelajaran matematika dikelas dapat diketahui dengan menggunakan instrumen lembar observasi aktivitas siswa selama pembelajaran matematika melalui penerapan model kooperatif tipe talking stick. Tekhnik yang digunakan untuk memperoleh data respons siswa menggunakn angket yang diberikan kepada siswa setelah penerapan pembelajaran tipe talking stick.

Data yang diperoleh akan dianalisis dengan menggunakan tekhnik analisis statistik deskriptif dan analisis statistik inferensial. Statistik deskriptif dilakukan untuk mengetahui hubungan variabel dengan melakukan analisis korelasi, dengan prediksi melalui analisis regresi, kemudian membuat perbandingan rata-rata data sampel atau populasi.

Analisis statistika deskriptif dimaksudkan untuk menggambarkan karakteristik hasil belajar matematika setelah penerapan pembelajaran model kooperatif tipe talking stick dengan meliputi: nilai rata-rata, nilai tertinggi, nilai terendah, nilai maksimum, nilai minimum, rentang, median, dan standar deviasi,

Kriteria yang akan digunakan dalam menentukan kategori hasil belajar matematika siswa kelas VII SMP Saribuana Makassar dalam penelitian ini adalah sebagai berikut:

Tabel 1. Kategorisasi Standar Hasil Belajar Siswa Yang Ditetapkan SMP Saribuana Makassar

\begin{tabular}{cc}
\hline Nilai & Kategori \\
\hline $0 \leq x<54$ & Sangat Rendah \\
$54 \leq x<74$ & Rendah \\
$74 \leq x<84$ & Sedang \\
$84 \leq x<94$ & Tinggi \\
$94 \leq x \leq 100$ & Sangat Tinggi \\
\hline
\end{tabular}

Uji Normalitas.

Untuk keperluan pengujian normalitas populasi digunakan uji One Sample Shapiro-Wilk dengan hipotesis:

$\mathrm{H}_{0}$ : Data berdistribusi normal

$\mathrm{H}_{1}$ : Data tidak berdistribusi normal

Digunakan kriteria yaitu diterima $\mathrm{H}_{0}$ apabila $\mathrm{P}$-value $\geq \mathrm{a}$, dan $\mathrm{H}_{1}$ ditolak jika $\mathrm{P}$-value $<\mathrm{a}$ dimana $a=0,05$. Apabila $\mathrm{P}$-value $>$ a maka $\mathrm{H}_{0}$ diterima, artinya data hasil belajar matematika setelah perlakuan berasal dari populasi yang berdistribusi normal.

\section{Hasil dan Pembahasan}

Hasil analisis tentang keefektifan pembelajaran matematika yaitu melalui penerapan pembelajaran model Kooperatif Tipe talking stick. Adapun indikator keefektifan dalam penelitian ini yaitu hasil belajar, observasi aktivitas siswa, dan angket respons siswa terhadap pembelajaran matematika dengan menerapkan model kooperatif tipe talking stick.

Data hasil proses pembelajaran matematika kelas VII SMP Saribuana Makassar sebelum menerapkan model kooperatif tipe talking stick dapat dilihat pada tabel 2. 
Tabel 2. Statistik Skor Hasil Belajar Matematika Sebelum Penerapan Model Talking Stick

\begin{tabular}{cc}
\hline Statistik & Nilai Statistik \\
\hline Ukuran Sampel & 26 \\
Skor Rata-rata & 33.13 \\
Variansi & 379.17 \\
Skor Tertinggi & 72 \\
Skor Terendah & 2 \\
Rentang Skor & 70 \\
Skor Ideal & 100 \\
Standar Deviasi & 1.94 \\
\hline
\end{tabular}

Selanjutnya ditemukan distribusi frekuensi \& persentase hasil belajar sebagai berikut:

Tabel 3. Distribusi Frekuensi dan Persentase Skor Hasil Belajar Matematika Siswa Sebelum Penerapan Model Talking Stick

\begin{tabular}{cccc}
\hline Skor & Kategori & Frekuensi & Persentase (\%) \\
\hline $0 \leq x<54$ & Sangat Rendah & 23 & 88.47 \\
$54 \leq x<74$ & Rendah & 3 & 11.53 \\
$74 \leq x<84$ & Sedang & - & - \\
$84 \leq x<94$ & Tinggi & - & - \\
$94 \leq x \leq 100$ & Sangat tinggi & - & - \\
\hline & Jumlah & $\mathbf{2 6}$ & $\mathbf{1 0 0}$ \\
\hline
\end{tabular}

Pada tabel diatas diperoleh bahwa dari 26 siswa kelas VII SMP Saribuana Makassar, 23 orang siswa dengan skor pada interval $0 \leq x<54$ artinya berada dikategori sangat rendah, dan 3 orang siswa memperoleh skor di interval $54 \leq x<74,74 \leq x<84$, dan $84 \leq x<94$, serta 94 $\leq x \leq 100$ artinya tidak terdapat siswa berada pada kategori rendah, sedang, tinggi, dan sangat tinggi. Rata - rata hasil belajar matematika siswa kelas VII SMP Saribuana Makassar sebelum penerapan pembelajaran model talking stick umumnya berada pada kategori sangat rendah.

Persentase ketuntasan hasil belajar sebelum menerapkan model pembelajaran kooperatif tipe talking stick pada tabel berikut.

Tabel 4. Deskripsi Ketuntasan Hasil Belajar Matematika Siswa Sebelum Penerapan Model Kooperatif tipe Talking Stick

\begin{tabular}{cccc}
\hline Interval Skor & Kategori & Frekuensi & Persentase (\%) \\
\hline $0 \leq x<75$ & Tidak Tuntas & 26 & 100 \\
$75 \leq x \leq 100$ & Tuntas & 0 & 0 \\
\hline Jumlah & & $\mathbf{2 6}$ & $\mathbf{1 0 0}$ \\
\hline
\end{tabular}

Hasil belajar matematika pada siswa kelas VII SMP Saribuana Makassar setelah menerapkan model kooperatif tipe talking stick. 
Tabel 5. Statistik Hasil Belajar Matematika Siswa Setelah diterapkan Model Kooperatif tipe Talking Stick

\begin{tabular}{cc}
\hline Statistik & Nilai Statistik \\
\hline Ukuran Sampel & 26 \\
Skor Rata-rata & 82.72 \\
Skor Terendah & 70 \\
Skor Tertinggi & 93 \\
Rentang Skor & 23 \\
Skor Ideal & 100 \\
Variansi & 38.87 \\
Standar Deviasi & 6.23 \\
\hline
\end{tabular}

Pada tabel di atas dapat dilihat bahwa siswa yang mengikuti post - test pada materi Bilangan Bulat sebanyak 26 orang. Dari lima soal essay yang diberikan, rata-rata hasil belajar pada siswa kelas VII SMP Saribuana Makassar setelah proses pembelajaran dilakukan dengan penerapan model kooperatif tipe talking stick yaitu 82.72 dari skor tertinggi 100. Skor yang dicapai tersebar dengan skor terendah 70 sampai skor tertinggi 93 dimana rentang skornya adalah 23. Nilai variansi sebesar 38.87 sehingga dapat dikatakan bahwa data yang peneliti peroleh bervariasi serta standar deviasi sebesar 6.23 yang berarti data tersebut beragam sehingga data tersebut mewakili semua populasi yang ada.

Hasil belajar matematika siswa kelas VII SMP Saribuana Makassar dapat dikelompokkan kedalam 5 kategori dalam bentuk distribusi frekuensi dan persentase sebagai berikut.

Tabel 6. Distribusi Frekuensi dan Persentase Skor Hasil Belajar Matematika Siswa Setelah Penerapan Model Kooperatif tipe Talking Stick

\begin{tabular}{cccc}
\hline Skor & Kategori & Frekuensi & Persentase (\%) \\
\hline $0 \leq x<54$ & Sangat Rendah & 2 & 7.7 \\
$54 \leq x<74$ & Rendah & 2 & 7.7 \\
$74 \leq x<84$ & Sedang & 13 & 50 \\
$84 \leq x<94$ & Tinggi & 9 & 34.6 \\
$94 \leq x \leq 100$ & Sangat tinggi & - & - \\
\hline & Jumlah & $\mathbf{2 6}$ & $\mathbf{1 0 0}$ \\
\hline
\end{tabular}

Pada tabel 6 diatas menunjukkan bahwa dari 26 siswa kelas VII SMP Saribuana Makassar terdapat siswa $(7.7 \%)$ memperoleh skor dengan interval $0 \leq \boldsymbol{x}<54$ artinya berada pada kategori sangat rendah, 2 orang siswa $(7.7 \%)$ memperoleh skor pada interval $54 \leq x<74$ artinya berada dalam kategori rendah, 13 orang (50\%) memperoleh skor pada interval $74 \leq x<84$ artinya berada dalam kategori sedang, 11 orang (34.6\%) memperoleh skor pada interval $84 \leq x<94$ artinya berada pada kategori tinggi, dan tidak ada siswa yang memperoleh skor pada interval $94 \leq x \leq$ 100, artinya tidak terdapat siswa berada dalam kategori sangat tinggi. Rata-rata hasil belajar siswa kelas VII SMP Saribuana Makassar setelah diajar dengan penerapan pembelajaran model kooperatif tipe talking stick secara umum berada pada kategori sedang. 
Adapun persentase ketuntasan belaar siswa setelah menerapkan model kooperatif tipe talking stick pada tabel 7.

Tabel 7. Deskripsi Ketuntasan Hasil Belajar Matematika Siswa Setelah menerapkan Model Kooperatif tipe Talking Stick

\begin{tabular}{|c|c|c|c|}
\hline Interval Nilai & Kategori & Frekuensi & Persentase (\%) \\
\hline $0 \leq x<75$ & Tidak Tuntas & 4 & 15.3 \\
\hline $75 \leq x \leq 100$ & Tuntas & 22 & 84.7 \\
\hline \multicolumn{2}{|c|}{ Jumlah } & 26 & 100 \\
\hline
\end{tabular}

Siswa yang memperoleh nilai paling sedikit 75 memenuhi kriteria tuntas secara individu, sedangkan apabila siswa di kelas mencapai sebesar 75\% yang memperoleh skor paling minimal 75 adalah memenuhi kriteria ketuntasan secara klasikal. Dari tabel 7 diatas menunjukan bahwa sebanyak 4 orang siswa yang tidak memenuhi kriteria ketuntasan yaitu persentase $15.3 \%$, sedangkan 22 siswa yang memenuhi Kriteria Ketuntasan Minimal dengan persentase 84.7\%. Sehingga dapat disimpulkan bahwa secara umum siswa kelas VII SMP Saribuana Makassar memenuhi Kriteria Ketuntasan Minimal (KKM = 75).

Hasil analisis data pembelajaran matematika sebelum penerapan model talking stick menunjukkan dari 26 siswa keseluruhan tidak ada satupun siswa yang mencapai KKM (nilai minimal 75), dengan kata lain hasil belajar siswa sebelum diterapkan model talking stick rata-rata masih tergolong sangat rendah dan tidak memenuhi KKM.

Setelah diterapkan model koperatif tipe talking stick dikelas VII SMP Saribuana Makassar, persentase ketuntasan hasil belajar matematika siswa berada pada kategori tinggi dengan skor rata - rata 82.72 dengan standar deviasi 6.23. Siswa yang tidak memenuhi Kriteria Ketuntasan Minimal sebanyak 4 siswa atau $15.3 \%$ dan yang memenuhi Kriteria Ketuntasan Minimal sebanyak 22 siswa atau $84.7 \%$. Ketuntasan klasikal tercapai apabila siswa di kelas memenuhi nilai minimal 75\%. Sedangkan 22 siswa di SMP Saribuana Makassar telah memenuhi kriteria ketuntasan yang dapat dilihat dari presentasenya sebesar $84.7 \%$.

Dengan demikian, dari hasil analisis data yang diperoleh menunjukkan bahwa hasil belajar matematika siswa tuntas secara klasikal, aktivitas siswa mencapai kriteria berhasil, serta respons siswa terhadap proses pembelajaran melalui penerapan model talking stick cenderung positif. Berdasarkan hal tersebut pembelajaran dikatakan efektif karena ketiga indikator keefektifan (Hasil belajar siswa, Responss siswa, dan Aktivitas siswa dalam proses pembelajaran terhadap proses pembelajaran) maka dapat disimpulkan bahwa "Pembelajaran matematika efektif melalui penerapan model talking stick pada siswa kelas VII SMP Saribuana Makassar".

Hasil analisis infferensial dapat dikatakan skor rata-rata hasil belajar matematika siswa setelah penerapan model kooperatif tipe talking stick tampak Nilai P adalah 0,001<0,05 artinya hasil belajar matematika siswa kelas VII SMP Saribuana Makassar mencapai KKM 75. Ketuntasan belajar siswa setelah diajar melalui penerapan model talking stick secara klasikal lebih dari atau sama dengan $75 \%$. Hasil analisis inferensial menunjukkan bahwa rata-rata gain ternormalisasi tampak bahwa nilai $t_{\text {hit }}=10.861$ menunjukkan bahwa rata - rata gain ternormalisasi pada siswa kelas VII SMP Saribuana Makassar lebih dari 0,29. Ini berarti bahwa $\mathrm{H}_{0}$ diterima dan $\mathrm{H}_{1}$ ditolak yakni gain ternormalisasi hasil belajar siswa berada pada kategori tinggi.

Dari hasil analisis deskriptif dan inferensial, ternyata cukup mendukung teori yang telah dikemukakan pada kajian teori sebelumnya. Dapat disimpulkan bahwa "Pembelajaran Matematika melalui Model Kooperatif Tipe Talking Stick Efektif digunakan pada Siswa Kelas VII 
SMP Saribuana Makassar". Pencapaian keefektifan melalui penerapan model talking stick dapat dilihat pada tabel 8 berikut:

Tabel 8. Pencapaian Keefektifan melalui Penerapan Model Kooperatif tipe Talking Stick

\begin{tabular}{cc}
\hline Kriteria Keefektifan & Kesimpulan \\
\hline Hasil Belajar Siswa & Tuntas dan Terjadi Peningkatan \\
Aktivitas Siswa & Aktif \\
Respons Siswa & Positif \\
\hline
\end{tabular}

\section{Simpulan}

Berdasarkan rumusan masalah, hipotesis dan hasil penelitian yang telah diuraikan dapat disimpulkan bahwa pembelajaran matematika efektif setelah diterapkan model kooperatif tipe talking stick pada siswa kelas VII SMP Saribuana Makassar, karena telah memenuhi indikator efektivitas pembelajaran yang ditetapkan yaitu ketuntasan hasil belajar matematika siswa, aktivitas siswa, dan respon siswa terhadap pembelajaran. Adapun secara spesifik untuk masingmasing indikator diuraikan sebagai berikut:

Hasil analisis deskriptif menunjukkan bahwa hasil belajar matematika siswa berada pada kategori tinggi, nilai rata-rata 82.72 setelah diterapkan pembelajaran model kooperatif tipe talking stick. Terdapat $84.7 \%$ atau 22 siswa yang memenuhi KKM dan 15.3\% atau 4 siswa yang tidak mencapai KKM.

Rata - rata peningkatan hasil belajar matematika siswa adalah 0.7305 . Nilai gain berada pada interval $\mathrm{N}$-gain $>0,70$ sehingga terjadi peningkatan hasil belajar siswa setelah diterapkan model talking stick dalam pembelajaran matematika pada siswa kelas VII SMP Saribuana Makassar dan termasuk kategori Tinggi.

Komponen penilain aktivitas siswa pada pembelajaran matematika dengan menerapkan model Kooperatif tipe talking stick berada dalam ketegori aktif dengan rata - rata $82.37 \%$. Dengan indikator keberhasilan aktivitas siswa sekurang-kurangnya $75 \%$ siswa yang terlibat aktif dalam pembelajaran. Dengan demikian aktivitas siswa mencapai kriteria baik.

Respon siswa terhadap pembelajaran matematika menunjukkan bahwa dari 5 aspek yang ditanyakan, respon positif siswa mencapai $90.6 \%$ dan respon negatif siswa yaitu $9.40 \%$. Hal ini menunjukkan bahwa siswa kelas VII SMP Saribuana Makassar merespon positif melaui penerapan model kooperatif tipe talking stick.

\section{Daftar Rujukan}

Amir, A. (2016). Pembelajaran matematika dengan menggunakan model kooperatif tipe talking stick. Logaritma: Pendidikan Matematika IAIN Padang, 4(1), 1-16.

Firdaus, A. M. (2019). Penerapan model pembelajaran kooperatif tipe think pair share (TPS) pada kemampuan komunikasi matematis. Daya Matematis: Jurnal Inovasi Pendidikan Matematika, 7(1), 59-68.

Khasanah Diah Laila, dkk. 2013. "Keefektifan Model Pembelajaran Talking Stick Terhadap Hasil Belajar Materi Pokok Aljabar". Unnes Journal of Mathematics Education (Online). Jurusan Pendidikan Matematika, FMIPA, Universitas Negeri Semarang. 
Made Ramayanti, dkk. 2011. “Pengaruh Penerapan Model Pembelajaran Kooperatif Tipe Talking Stick Terhadap Hasil Belajar Matematika (Studi Eksperimen pada Materi Bilangan Bulat di Kelas VII SMPN 1 Sausu)". Jurnal Elektronik Pendidikan Matematika Tadulako, Volume 02 Nomor 02, Desember 2014 (Online).

Mallisa, P. L. (2014). Penerapan Model Talking Stick Dalam Pembelajaran Matematika Siswa Kelas VII SMP Negeri 2 Sangalla'. Jurnal Keguruan dan Ilmu Pendidikan, 3(2), 533-536.

Meriam Belina, dkk. 2015. “Penerapan Model Talking Stick Pada Pembelajaran Matematika Siswa Kelas VII SMP Negeri Air Satan Tahun Pelajaran 2015/2016". Jurnal Pendidikan Matematika (Online).

Sugiyono. 2015. Metodologi Penelitian Pendidikan (Pendekatan Kuatitatif, Kualitatif, dan RED). Bandung: Alfabeta.

Suprijono, Agus. 2009. Cooperative Learning (Teori dan Aplikasi). Yogyakarta 55167. Pustaka belajar.

Suyitno, A. 2004. Dasar-Dasar Proses Pembelajaran Matematika 1. Semarang. Unnes Press.

Syarif Hidayanti, dkk. 2017. “Perbandingan Hasil Belajar Matematika Pada Model Pembelajaran Kooperatif Tipe Talking Stick Dan Student Teams Achievement Division Materi Aljabar Bagi Siswa Kelas VII SMP Negeri 2 Tuntang". Jurnal Pendidikan Matematika (Online). Jurusan Pendidikan Matematika FKIP. Universitas Kristen Satya Wacana. Salatiga.

Tim Penyusun FKIP Unismuh Makassar. 2014. Pedoman Penulisan Skripsi (Edisi Revisi 1). Makassar. 
